\title{
Representations about sexuality of people diagnosed late with HIV infection
}

\author{
Representações sobre sexualidade de pessoas diagnosticadas tardiamente com a infecção pelo HIV \\ Representaciones sobre la sexualidad de personas diagnosticadas tardíamente con infección por VIH
}

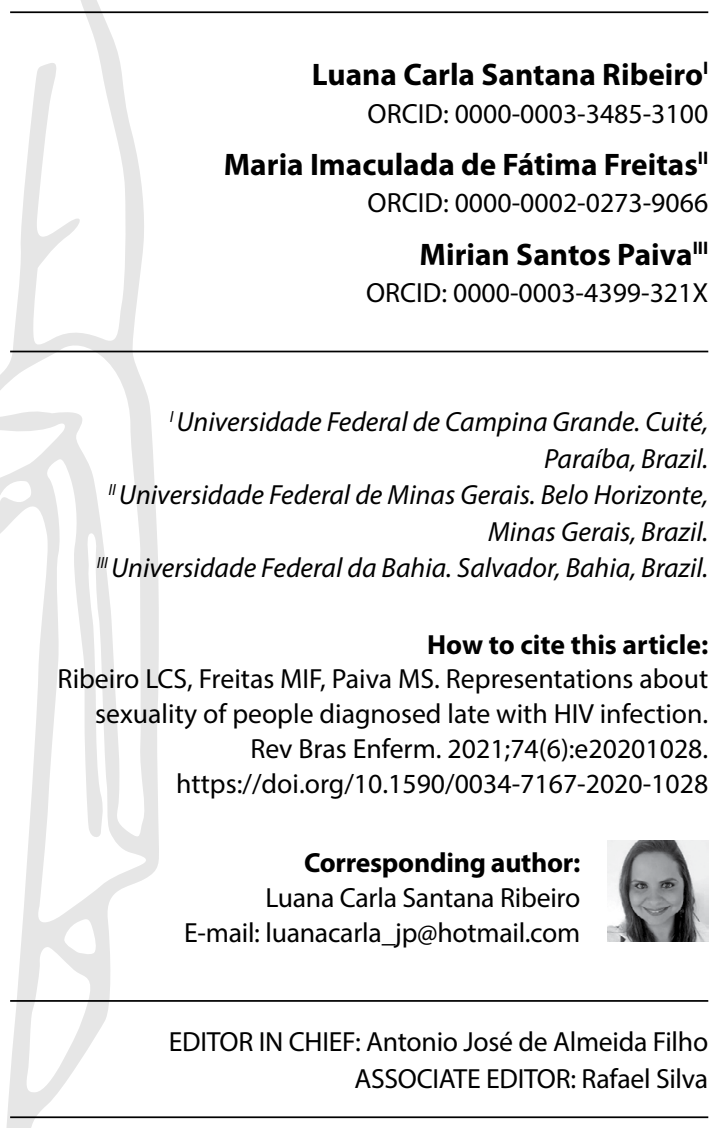

Submission: 10-07-2020

Approval: 03-29-202

\begin{abstract}
Objective: to understand the representations about sexuality of people diagnosed late with HIV infection and its implications in the delayed search for diagnosis. Methods: this is a qualitative study, whose theoretical and methodological framework was Social Representation Theory. The research was carried out with 18 people diagnosed late with HIV infection through an open interview. For data analysis, Structural Narration Analysis was used, with support from MAXQDA $12^{\circ}$. Results: representations about sexuality contributed to delayed diagnosis, such as trust in a fixed partnership, sexual intercourse is natural, sexuality as a taboo, search for pleasure in sexual intercourse, regardless of risks, denial of risk for HIV infection. Final considerations: representations about sexuality participate in a web of stereotypes and riskier ways of living, which contribute to delayed diagnosis. Sexual health education remains necessary and essential throughout people's lives.
\end{abstract}

Descriptors: HIV; Acquired Immunodeficiency Syndrome; Delayed Diagnosis; Sexuality; Qualitative Research.

\section{RESUMO}

Objetivo: compreender as representações sobre sexualidade de pessoas diagnosticadas tardiamente com a infecção pelo HIV e suas implicações na busca atrasada por diagnóstico. Métodos: estudo de natureza qualitativa, cujo referencial teórico-metodológico foi a Teoria das Representações Sociais. Realizou-se a pesquisa, com 18 pessoas diagnosticadas tardiamente com a infecção pelo HIV, por meio de entrevista aberta. Para análise dos dados, utilizou-se a

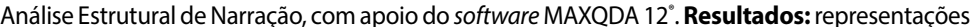
sobre sexualidade contribuíram para o diagnóstico tardio, tais como, confiança em parceria fixa, relação sexual é natural, sexualidade como tabu, busca pelo prazer na relação sexual independente dos riscos, negação do risco para infecção pelo HIV. Considerações finais: representações sobre sexualidade participam de uma teia de estereótipos e de modos de viver mais arriscados, que contribuem para a descoberta tardia da infecção. A educação em saúde sexual permanece necessária e fundamental ao longo da vida das pessoas.

Descritores: HIV; Síndrome de Imunodeficiência Adquirida; Diagnóstico Tardio; Sexualidade: Pesquisa Qualitativa.

\section{RESUMEN}

Objetivo: comprender las representaciones sobre la sexualidad de personas diagnosticadas tardíamente de infección por VIH y sus implicaciones en la búsqueda tardía del diagnóstico. Métodos: estudio cualitativo, cuyo marco teórico y metodológico fue la Teoría de las Representaciones Sociales. La investigación se llevó a cabo, con 18 personas diagnosticadas tardíamente de infección por $\mathrm{VIH}$, a través de una entrevista abierta. Para el análisis de los datos se utilizó Structural Narration Analysis, con soporte del software MAXQDA $12^{\circ}$ Resultados: las representaciones sobre la sexualidad contribuyeron al diagnóstico tardío, como la confianza en una pareja fija, la relación sexual es natural, la sexualidad como tabú, la búsqueda del placer en la relación sexual, independientemente de los riesgos, la negación del riesgo de infección por VIH. Consideraciones finales: las representaciones sobre la sexualidad participan en una red de estereotipos y formas de vida más arriesgadas, que contribuyen al descubrimiento tardío de la infección. La educación en salud sexual sigue siendo necesaria y esencial a lo largo de la vida de las personas.

Descriptores: $\mathrm{VIH}$; Síndrome de Inmunodeficiencia Adquirida; Diagnóstico Tardío; Sexualidad; Investigación Cualitativa. 


\section{INTRODUCTION}

Early diagnosis of Human Immunodeficiency Virus (HIV) infection and timely initiation of antiretroviral therapy (ART) are priority strategies for coping with the pandemic, aiming at reducing morbidity and mortality, preventing new cases of infection and promoting quality of life of people living with HIV (PLHIV) $)^{(1-2)}$.

The high prevalence of people who are diagnosed late and who show up late for care with HIV infection, observed in Brazil and other countries ${ }^{(3-5)}$, constitutes an emergency problem to be considered in the response to pandemic. This problem is configured as a complex and multifactorial phenomenon, which, in addition to being associated with sociodemographic ${ }^{(4-6)}$ and sociocultural factors ${ }^{(7-8)}$ and referring to barriers of health services ${ }^{(9-10)}$, relates to psychosocial aspects such as subjectivities and representations about HIV/AIDS that influence the search for diagnosis by vulnerable people ${ }^{(11)}$.

Studies have analyzed discourses and representations about PLHIV sexuality and its influence in the process of vulnerability to infection, highlighting the confidence in a fixed partnership as a mediator of unprotected sexual practices; the permanence of old stigmatizing stereotypes, such as AIDS related to promiscuity, the multiplicity of sexual partnerships and the feeling of shame, which contributes to failure to recognize their own vulnerability; the unequal power relations between genders in affective-sexual relationships, which affect the negotiation of condom use $\mathrm{e}^{(12-13)}$; the speeches and attitudes of hegemonic masculinity ${ }^{(14)}$; the stigma related to male homosexuality as a barrier to HIV testing ${ }^{(15)}$.

Research carried out with health professionals and older adults pointed out aspects related to sexuality that can favor the occurrence of delayed diagnosis for the infection, such as invisibility of sexuality of this public for health professionals and subsequent lack of dialogue on issues during visits ${ }^{(16)}$. However, there is a gap in published literature on representations of PLHIV's sexuality and its possible influence on the occurrence of delayed diagnosis, from the perspective of health users in general.

The representations influence the way PLHIV think and act, greatly influencing their life trajectories and their affective and sexual relationships, being also influenced by them. It is noteworthy that the ideas, concepts, discourses and actions related to sexuality are constituted in the socio-cultural and historical contexts in which people live ${ }^{(17)}$. They construct, seize and introject representations about sexuality, at the same time that they act in the permanence or in the modification of these representations, through their interactions.

Thus, the following question guided this research: what are the representations about sexuality of people diagnosed late with HIV infection and its implications in delayed search for diagnosis?

\section{OBJECTIVE}

To understand the representations about sexuality of people diagnosed late with HIV infection and its implications in the delayed search for diagnosis.

\section{METHODS}

\section{Ethical aspects}

In compliance with the Brazilian National Health Council (CNS - Conselho Nacional de Saúde) Resolution 466/2012, the research was approved by Institutional Review Boards. Participants signed the Informed Consent Form and, with the objective of guaranteeing their anonymity, the interviewees were called E1, E2 and so on, according to the sequence of the interviews.

\section{Theoretical-methodological framework}

Social Representation Theory (SRT) was used as a theoreticalmethodological framework, based on critical approach ${ }^{(18)}$.

According to this approach, representations come from different sources in social relations, and not only from the transformation of scientific knowledge into common sense, are organized around a deep core, called original representations, and persist in personal and professional experiences. In addition to this central nucleus, there are peripheral elements, which are flexible to changes and reformulations. Thus, the original representations are the oldest ones chronologically and that constitute the structuring nucleus of the system of communions represented more widely. The peripheral representations are more related to the proximity in the relationships with people who live the situation, i.e., they are infected with HIV(18).

\section{Type of study}

This is a qualitative cut of research with a mixed approach, based on constructivist approaches to sociology, guided and structured with reference to the Consolidation Criteria for Qualitative Research Reports (COREQ).

\section{Methodological procedures}

\section{Study setting}

This research was carried out in the state of Paraíba, northeastern Brazil, in which the occurrence of $59.1 \%$ of delayed diagnosis was observed, according to the quantitative cut of the study ${ }^{(4)}$. The settings of this research were Specialized Assistance Services (SAS) and the homes of PLHIV diagnosed late.

\section{Data source}

The study was conducted with 18 people who were diagnosed late with HIV infection. The sample was intentionally reached and its size was delimited by theoretical saturation ${ }^{(19)}$.

PLHIV in ART who had a delayed diagnosis (LT-CD4 + count at the time of diagnosis less than 350 cells $/ \mathrm{mm}^{3}$ ) and who provided information regarding the landline or cell phone number, in addition to consenting to further contacts were included. PLHIV who had a delayed diagnosis, but were hospitalized during the period of qualitative data collection, and residents outside the metropolitan region of João Pessoa were excluded. 


\section{Data collection and organization}

The technique of data collection used was open interview whose script contemplated a central question regarding participants' life trajectory until the diagnosis of HIV. Data were collected in August 2017 by the responsible researcher with previous experience in qualitative interviews, in places chosen by interviewees, which consisted of their homes or SAS in which they are followed. In both situations, the interviews, which lasted an average of 22 minutes, were conducted in an environment that provided privacy to participants and after written consent. The interviews were recorded with participants' agreement, and, later, transcribed and validated through peer review.

\section{Data analysis}

The method used for data analysis was Structural Narration Analysis ${ }^{(20)}$. This method was implemented using the MAXQDA 12 software as a tool, with the main functions of organizing the texts and coding the empirical material. For validating the codification of narratives in MAXQDA, a peer review was carried out. As parameters to implement intercoder agreement analysis between peers, the percentage of correlation between coded textual segments corresponding to $80 \%$ and the acceptable Kappa index from $75 \%$ were used.

From analysis of interviewees' narratives, representations were unveiled that were organized and outlined according to the expression of density and importance for participants, being constituted in original and peripheral representations.

\section{RESULTS}

All study participants were diagnosed late, i.e., with an LT-CD4 + count at the time of diagnosis of less than 350 cells $/ \mathrm{mm}^{3}$. Regarding their sociodemographic characteristics, $50.0 \%$ of them reported being male; $50.0 \%$ were female; $61.1 \%$ were in the 25 to 49 age group at diagnosis time; $77.8 \%$ were brown; $50.0 \%$ were married or in a stable relationship at the time of diagnosis; the majority (66.7\%) were Catholic at the time of discovery of the infection; $50.0 \%$ had 12 years or more of study; $33.3 \%$ had low education, from 1 to 8 years of study; $72.2 \%$ declared themselves to be heterosexual; the majority of participants (66.6\%) acquired HIV infection from sexual intercourse with men ${ }^{(11)}$.

From the understanding of the original representations related to PLHIV's sexuality, diagnosed late, the following theoretical categories were constructed: Sexual intercourse is natural; It is in adolescence that sexual life begins; Sexuality as a taboo; Trust in a fixed partner; Heterosexuality: man is polygamous and woman is monogamous; Denial of risk for HIV infection. The representation of the search for pleasure in sexual intercourse, regardless of the risk of infections, permeated all the others.

\section{Sexual intercourse is natural}

The narratives of affective sexual relationships before and after HIV diagnosis revealed the central representation that sexual intercourse is natural and integrates the different phases of people's lives. Derived from this original representation, the peripheral representation arose that sexual desire is a natural and uncontrollable impulse, which, in turn, is linked to the central representation of the search for pleasure in sexual intercourse, regardless of infections or diseases ${ }^{(17)}$.

[...] I didn't feel anything, I was fine, I was just at the peak, every month I was: "Come on, come on!" Every month he came, we played a game. We played, stayed inside the room, sometimes arrived from eight in the morning and left the room at four in the afternoon. [...] we went to parties [...]. Then I started taking contraceptives, because the guy just wanted it without a condom. (E6, heterosexual woman, 38 years old)

There were several women in my life! I worked in the factory too, I went out with a lot of women. Generally, factory, industry, there are a lot of women, right? Then, I would go out with anyone, I didn't have a prevention and I didn't look at anything. [...] because I thought [the condom] bothered me! [...] I used to go out with colleagues, I got a disease right away, I got it five times. (E12, heterosexual man, 59 years old)

\section{It is in adolescence that sexual life begins}

Most of life trajectories revealed the beginning of sexual life in adolescence, as a pattern to be followed, a probable stereotype in people's daily lives.

I had my first relationship at the age of thirteen, then it was the person I lost my virginity with... I married him, right? And I spent seven years with him. [...] I saw it, but I didn't understand it! Due to age too, I had no knowledge, but I saw how to prevent it, the condom, always using a condom. Only I didn't understand! [...] (E1, heterosexual woman, 19 years old)

[...] but when it was about ten years old, I knew something different inside of me. My thing was, so / wanted to have a relationship with a man [...]. It was with a man [sex]. (E9, bisexual man, 60 years old)

I think I was about eighteen. I did not use [condom on sex] [...]. Then, I dated like this and we had sex. Then, I got married, I spent twelve years married to the father of my children. (E10, heterosexual woman, 44 years old)

\section{Sexuality as a taboo}

Analysis of narratives revealed the central representation of sexuality as a taboo, for itself, and, particularly, in the field of the dialogue of micro-relationships.

My mom didn't know, my dad didn't know. I didn't have the courage to tell them that, right? I was already a mature woman. I was already in my thirties, but I was practically not a little girl, a brat. I was aware that I was doing the wrong thing, but at the same time I was enjoying it, enjoying naughtiness. (E6, heterosexual woman, 38 years old)

[...] but I had a relationship with my wife at home. I was married and, on the street, when I went out, I had a relationship with men too, understand? When it happened, it happened! I stayed here 
wondering what that would be like. And I didn't want to accept that and that reaction, you know! I also didn't want to do that with men. That made me feel bad [...]. I thought it was horrible for the man, I thought it was ugly [...]. (E9, bisexual man, 60 years old)

Imbricated in this representation, the peripheral representation expressed in the absence of dialogue with parents about sexuality, in the silence of sexual discourse in the family context, is unveiled.

My parents are very subtle, so they let life teach, you know? Yes, but it was more through the school itself. And with people, on a daily basis and I was learning, reading, looking for information. (E5, homosexual man, 37 years old)

My mother is one of those who does not talk, because we think it is good when we have a mother who talks, explains everything. [...] she wasn't meant to talk, talk about sex life or illness. She did none of this, and because I was so stuck at home, I didn't have access to people who could talk to me about these things. [...] then, I wasn't supposed to go out, so much so, that when I went to see the world, it was with my seventeen years old, the first guy I met I related, I went to live together. (E14, heterosexual woman, 24 years old)

I didn't have any information with my parents, because they are kind of restrained about it. (E17, homosexual man, 31 years old)

As one of the repercussions of sexuality as a taboo, the attitude of denying one's vulnerability to HIV is identified. In the statements below, it is evident that there is knowledge about the screening test, but not the practice of performing it, due to lack of interest or lack of concern, which reflects the feeling of invulnerability.

I knew, I knew [about HIV test], but I was not interested. I didn't feel anything, I was really fine. (E6, heterosexual woman, 38 years old)

I knew it existed! I knew the test existed, understand? But I'm going to tell you, I didn't do it, I was never interested in doing it. Now I was interested in the time when I saw the thing deepening, which is what happened and even this thing came to the point of discovering it. (E9, bisexual man, 60 years old)

I had never done it! So, I had heard of it, but it never crossed my mind. There were even lectures at the company about HIV, but I was never interested. (E15, homosexual man, 33 years old)

The representation of sexuality as a taboo is also revealed in health professionals' conduct:

I used only cytology, you know? So, just to know if there was any inflammation, oozing, nobody asked anything. So, when I was suspected of pregnancy, I still did it, you know? [...] but it was negative, then I didn't do it anymore. (E1, heterosexual woman, 19 years old)

[...] when a doctor asks for an exam like that is because things are ugly for the guy. Asking to know what his problem is, because usually the guy will not say, "I want to have an HIV test". (E4, heterosexual man, 36 years old)

I did the cytology and colposcopy tests, which were private, I always did mammography, transvaginal, once a year. [...] I never had a request for an HIV test! [...]. [...] but I always talked like that, I wanted to do it, but I didn't know where to do it. I never looked for it, I think I was afraid, there are always a lot of known people who work at the health center [...]. (E7, heterosexual woman, 44 years old)

\section{Trust in a fixed partner}

A central representation that marked PLHIV's lives was the trust spent with their fixed partners in their sexual affective relationships. Men and women, in heterosexual or homosexual relationships, established the attitude of trust as a mediator of the routine practice of unprotected sexual relations.

[...] there comes a time when that friendship becomes a serious love, then I believe that condoms there no longer work. Here's the problem! [...] / believe that one starts to trust the other, right? [...] (E4, heterosexual man, 36 years old)

I still used condoms, right? When it was necessary, but I met someone in my life that I fell in love with. Love at first sight, I fell in love! [...] / trusted him; he gave me confidence. [...] do you know when a person goes blind liking a person? [...]. I wanted to satisfy his will. (E6, heterosexual woman, 38 years old)

[...] so, after many people that I had a relationship with, but always very safely, I had a six-year relationship and that's when I gave up the condom, you know? [...] as it had been a long time, he always asked and I would say, "no, I don't think there is any problem, I think it's been a long time since we've been together, it's the person I really want to end my life with, I want to build something". So, who else do you believe in? If you trusted someone you loved and then you know all of that, I would be crazy, you know? [...] (E13, homosexual man, 31 years old)

\section{Heterosexuality: man is polygamous and woman is monogamous}

The original representation that man is polygamous, and woman is monogamous, by nature, appeared with considerable force in heterosexual interviewees' narratives, revealing the intensity of the anchoring of this representation in social imagination.

Then, I had confidence in him, right? I just went with him, but the man is never like that, he is not satisfied with a woman at home, he always looks for others, then I would never think that. I always trusted him, I thought he only had it with me. Then, I didn't put it in my head, then I asked him and he said he didn't go out with anyone. Then, when I separated, I found out I had the disease. (E1, heterosexual woman, 19 years old)

Because I thought, out there that he was a person of life, I thought that he prevented himself. [...] he had his wife at home, he lived outside to get involved with other women, but then he prevented himself, but it was the other way around, we are what we see. Most wives get it from their husbands. (E7, heterosexual woman, 44 years old)

[...] but even because he was very manly, so when we started to get involved, I didn't want to use it. [...] we used it after a lot of fighting, after a lot of fighting, because I wanted to and he didn't. 
[...] we used to argue and as I was very submissive at the time, sometimes time I used it, sometimes I didn't. (E14, heterosexual woman, 24 years old)

\section{Denial of risk for HIV infection}

One of the peripheral representations that sustained the permanence of risk denial in subjects' experience was the feeling of invulnerability.

\begin{abstract}
Ah, I knew! The staff told me it was in the relationship, but that didn't go into my head. Now after I got it, I got into reality [...]. (E4, heterosexual man, 36 years old)
\end{abstract}

Doyou know why? I thought it would never happen to me. I thought it would never happen [...]. (E9, bisexual man, 60 years old)

Feeling invulnerable, sexual risk behavior associated with alcohol consumption is associated.

The first time [sex], I used [condom]! But, as I was going out with him alone, I started going out with him, so he didn't want to use it anymore. Then, I didn't worry too. He was crazy and drank too. Then, I didn't even care, neither I nor he. (E1, heterosexual woman, 19 years old)

[...] then, I went out a lot with friends, went out to drink [...] / didn't have any prevention and didn't look at anything. (E12, heterosexual man, 59 years old)

\section{DISCUSSION}

It is seized in the narratives a contradiction between the free experience of sexuality in its various forms and the concern with sexually transmitted infections, which influences the non-use of condoms and, as a consequence, exposure to HIV infection occurs, without the awareness of vulnerability ${ }^{(17)}$.

Traditionally, in society, there is a fundamental belief that sexuality is a natural impulse of powerful force, which arises in people's lives in one way or another and that requires repression and control, aiming at their protection or liberation, with the objective main self-realization. The quality of sex as something natural is one of the central ideological elements of liberal and conservative conceptions regarding sexual conduct ${ }^{(21)}$.

Researches show that, despite the knowledge about ways to prevent STIS/HIV, such as the use of condoms during sexual intercourse, subjective issues and representations influence the decision not to use them, such as the unpredictability of sexual intercourse ${ }^{(22)}$, which reveals the representation of sex as a strong and difficult-to-control desire, and the decrease in intense and natural pleasure, which is expected from unprotected intercourse, delegitimizing the use of condoms, despite possible consequences, such as transmission infections or diseases and unwanted pregnancies ${ }^{(23-25)}$.

Regarding the representation that sexual life must necessarily begin during adolescence, it is known that this practice has been scripted in Western culture since modern times. The beginning of sexual life generally occurs in the adolescence phase, but in a different way among people, as each one is influenced by their family, socioeconomic and cultural context of life, as well as by the introjected and shared representations in social groups about the dynamics of sexual affective relationships, sex and sexuality. In general, for women, sexual intercourse is permeated by representations linked to love and pleasure, while for men, they occupy the centrality of representations, the search for physical pleasure and the practice of sex with many partners throughout of life ${ }^{(25)}$.

It is noteworthy that it was common not to use condoms during sex, representing for these individuals the beginning of a life marked by vulnerability to HIV. The increasingly early initiation of sexual life favors exposure to HIV and other STIs, due to the adolescents' own immaturity, which bring, at its core, the desire for new experiences without thinking about the consequences and the construction of self-identity. Furthermore, there is a lack of dialogue with parents about sexuality and an insufficient approach to the topic at school and in health services ${ }^{(17)}$. It also highlights the influence of social media in the construction of adolescents'self-identity ${ }^{(26)}$, their representations about sexuality and the routing of their sexual life and interpersonal relationships ${ }^{(27)}$. The early onset of sexual life during adolescence, as an aspect that contributes to vulnerability to HIV and other STIs, was also noted in other studies ${ }^{(25,28-31)}$.

Sexual attitudes and habits start in adolescence, at the beginning of sexual life, are consolidated in experiences and persist throughout life trajectories, and it is necessary that the perception of their own vulnerabilities and the practice of protected sexual relations be emphasized from this stage of life. It is often observed that knowledge about STIs and forms of prevention is inadequately apprehended by adolescents, who express erroneous information, full of beliefs and myths. Thus, evaluating the conceptions, attitudes and practices regarding HIV among adolescents helps to develop appropriate prevention strategies for this public (28).

The barriers to understanding and approaching sexuality occurred, primarily, in an intra-individual dimension, leading to contradictions between sexual ideas and discourses and sexual actions. Thus, taboos engender, above all, the prohibition of talking about sex, of having desires that do not fit into a partnership considered to be of a normative standard - man/woman, to express doubts, among many others.

The historical contradiction between public and private life permeates social daily life and influences the way of thinking and acting of individuals. Despite the widespread dissemination of information about sex and sexuality and the transformations that have taken place in contemporary sexual practices, people continue to shape their discourses through what society considers morally correct or accepted, which is strongly influenced by culture and religion in the United States. their life contexts. In Brazil, there is a great influence of Christian precepts, in what society establishes as the correct conduct in the area of sexuality, such as valorization of monogamous and conjugal relationship and heterosexuality as the correct pattern of sexual behavior. In some narratives, the representation of homosexuality itself as a taboo also emerged, which led, in certain moments, to the experience of heterosexual relationships as a way of covering up sexual desire by people of the same sex.

In this way, the persistence of a gap between the individual discourse on sexuality and sexual conduct itself is evident. This detachment unfolds in the difficulty of understanding and dialoguing with others about their own sexuality. These others, belonging to 
the subjects' micro-relationships, can be relatives, friends, affective sexual partners or even educators or health professionals.

People start their sex lives early, often in their early teens, and often without ever having a dialogue with parents or guardians in their family about sex, gender identity or sexuality. Despite the cultural changes of the last few decades, it is still common for many parents to remain silent on these issues, which transfer the responsibility for sex education to schools. Thus, according to many speeches, the learning of sexuality usually happens from the experiences themselves, from the daily life of friendships and from access to information from social media.

It is known that adolescents who receive adequate support from their guardians have statistically higher levels of preventive attitudes and less risky behavior ${ }^{(28)}$. Research carried out with adolescents identified that some of them did not miss a dialogue with parents about sexuality, due to the feeling of shame, which motivated them to seek knowledge with friends, over the internet or with health professionals ${ }^{(30)}$. According to the results of the aforementioned research, friendships are considered by adolescents to be one of the main sources of sexual information or, at least, their origin, because they are their peers, with a focus on the sexual act, and very little about the forms of prevention.

Thus, adolescents experience their sexuality without being prepared and aware of the challenges of intimate relationships, and do not know how to deal with their own feelings and those of their partners. In addition, they lack the self-perception of the risks of unprotected sex and their vulnerabilities to HIV and other STIs, which should be built at the beginning of their sexual intercourse. This lack of perception about their own vulnerabilities contributes to an attitude of continuous denial of risk for HIV infection and, consequently, to the possible exposure to the virus due to unprotected sex and subsequent delayed diagnosis due to lack of screening.

The results show that having the information that there is an exam to detect HIV is not enough for the implementation of this preventive measure by the user, being necessary the awareness of vulnerability, which requires the (re) construction of new representations about sexuality, HIV and AIDS.

In addition to lack of perceived vulnerability to HIV, which leads to the attitude of not tracking the virus, it is noteworthy that, despite the fact that people are seen in health services for various reasons, health professionals, at all levels of care, particularly in Primary Health Care (PHC) and on an outpatient basis, they often do not request the HIV test in a timely manner, in addition to not talking about the sexuality of health users.-

The HIV test is often requested only after the user is suspected of becoming ill, revealing a delayed diagnosis, or as a prenatal routine, according to the Ministry of Health $(\mathrm{MoH})$ protocol. This fact probably occurs due to lack of dialogue between health professionals and users about sexuality, resulting from fragmented care, centered on the disease and essentially curative. This fragmentation of health care is explicit in the case of the Women's Health Program of PHC in Brazil, which recommends, among other measures, periodic cytopathological examination. Generally, the consultation that should consider women in their entirety, including their sexuality, regardless of age, is restricted to the exam collection and breast screening. It would be through a dialogical approach that professionals would identify, for instance, the practice of sexual intercourse without a condom and request HIV test in a preventive way, aiming at a possible timely diagnosis. The dialogue would also provide an opportunity to share information about sex and sexuality and lead to the process of raising awareness of vulnerabilities to HIV and other STIs.

The speeches also expressed strong representations about the trust existing in a stable relationship, which consists in believing that the partner is faithful and monogamous, that is, he is not able to engage in casual relationships with other people. This results in the individual who trusts the feeling of security and protection, including against HIV and other infections. Implicit in this representation, the idea that the current partner does not have the virus, is manifested in the attitude of denying the vulnerability.

There are also traces of the ideology of romantic love, socially scripted, symbolically permeated by expectations of lasting romance and that the other is the right person to establish a loving relationship, in which sexual exclusivity is assumed. Trust, essentially, is a legitimate attitude in interpersonal relationships, however, when blind, it loses its legitimacy in social interactions ${ }^{(32)}$.

During the narratives, it is clear that this trust in the fixed partnership is so devout, that it directs the person to the projection of a risk-free affective relationship, with the idealization that the partner has a "clean" body, without diseases or infections and thus free from HIV. In this way, the representation that sexual intercourse with a steady partner and without a condom is "legitimate" is revealed, which expresses the naturalization of unprotected sex in a stable or lasting relationship.

Romantic love presupposes the idealization of the loved one and a psychic connection, a meeting of souls in which the other fills the void of individuals, making it complete. In this way, it is linked to the issue of intimacy and self-identity. This kind of love is expressed by the support in the other and by its idealization, as well as it is projected for the future, unveiling the dreamy quality of the romance. Furthermore, it is necessarily monogamous, in which the partner's fidelity is idealized in terms of his sexual and affective exclusivity ${ }^{(33)}$.

The attitude of trust in the affective partnership as a factor of protection against HIV/AIDS, as a mediator of feeling invulnerable to infection and, therefore, as a motivator for the non-use or inconsistent use of condoms in sexual relations, was also evidenced in others studies ${ }^{(23-24,34-35)}$

Generally, in stable monogamous relationships, the practice of protected sexual relations is limited to the beginning of relationships and, as time goes by, the ability to negotiate condom use decreases, with the abandonment of its use occurring ${ }^{(22,24)}$. This practice happens since the beginning of sexual life in adolescence ${ }^{(36)}$, understanding that the representations of sexuality and gender are introjected since this stage of life, becoming central in the trajectories of individuals.

The attitude of trust in a stable partnership can, therefore, contribute to not using condoms during sexual intercourse, as well as to not carrying out periodic screening of the virus after these unprotected relationships, corroborating for a delayed discovery of HIV infection.

In the analysis of trust in a fixed partnership as a mediator of the non-recognition of one's vulnerability to HIV, it is emphasized that the attitude of trusting the partner does not necessarily have the same 
fundamentals for men and women. For men, trust in their partner means belief in their total fidelity; in contrast, for women, trust does not refer, in a restricted way, to believing in the exclusivity of sexual relations, but also in the belief that their partner would not put her at risk, establishing extramarital relationships without a condom ${ }^{(24)}$.

In the field of affective relationships and sexuality, gender issues have a great influence on the dynamics of relationships, especially on the definition of roles of men and women in heterosexual relationships. The traditional representations of male and female sexuality are based on the extremely opposite dichotomy of the biological and uncontrollable nature of male sexuality on the one hand, and the "spiritual", psychological and controllable nature of female sexuality, on the other hand, which is intensely linked to ideals of romantic love ${ }^{(37)}$.

In this sense, the unfaithful and polygamous behavior of many men is explained by them, as a strategy to always keep their sexual desires satisfied, since, by establishing sexual relations with multiple partners, when one refuses the sexual act, the other accepts. Additionally, the conduct of sexual exclusivity in a conjugal relationship can be threatened through marital conflicts and the experiences of "temptations", when there are opportunities to have sex with other women considered "beautiful", the refusal being considered a denial of their own masculinity. Thus, the sense of power in relationships between men and women, as well as the search for new emotions, are explanations given by men to justify their polygamy ${ }^{(38)}$.

The behaviors of men and women are defined by the social roles constructed in their socioculture, as representations that become stereotypes or social truths that remain over time. Regarding their sexuality, it has been determined, historically, that the woman does not belong to her own body and dominates her sexuality, but it belongs to the man, considered as the strong sex of the relationship. Thus, despite the changes that have taken place in society in recent decades, there are signs of these representations of hegemonic masculinity, allowing men to enjoy an unstoppable sexuality, with multiple sexual partners ${ }^{(36)}$.

The fact that the man refuses to use condoms or that his partner consents to unprotected sex was recurrent in many participants'life stories. Other studies have also found difficulties in negotiating condom use in sexual relations, with the man concentrating the final decision power within himself, which is often the negative, and the woman submitting to the male decision so as not to disappoint the partner or harm the sexual experience with the imagined feeling of mistrust (linked to the attitude of wanting to protect oneself) or by not wanting to be "guilty" for the decrease or for the said lack of pleasure, arising from the protected sexual act.

It is interpreted that although there is a representation in the imaginary of women that a man is polygamous, in his relational experiences, trust in the faithfulness of the man who is his loving partner prevails, or at least the certainty that he preserves woman of the house", relating to a condom with the "woman from the street". In both situations, the representations that the male partner is reliable and, ideally, free of diseases or infections like HIV, engender in women the decision to have unprotected sex, without awareness of their vulnerability to HIV. This fact corroborates delayed search for diagnosis.

The original representation of denial of risk for HIV infection occupied the centrality of PLHIV's life trajectories. Failure to recognize their own vulnerability to HIV is implicated in all other representations and greatly influenced the delayed search for diagnosis, given that people had sex without a condom throughout their lives, exposing themselves to infection, but did not consider perform the screening after these unprotected relationships ${ }^{(17)}$.

Feeling invulnerable reveals that people believed that they were in control of their lives and that their attitudes could not harm them, such as HIV infection. In this way, there is a disjunction between the knowledge about the sexual transmission of the virus and the individual awareness of vulnerability, permeated by other representations of AIDS, such as stereotyped disease that affects only the other ${ }^{(11)}$. The feeling of invulnerability actually intensifies the process of vulnerability to AIDS. Research carried out on self-perceived risk of HIV identified that more than half of the people investigated did not consider themselves vulnerable to infection or considered themselves at low risk ${ }^{(31,39)}$.

The self-perception of HIV invulnerability is strongly influenced by the development of positive illusions, mainly the unrealistic optimism about the future and the illusion of control over negative events, including diseases ${ }^{(40-41)}$. This invulnerability to HIV is directly related to the absence of preventive practices in sexual behavior, such as the use of condoms in various sexual activities and the screening for the post-exposure virus, which predisposes people to a late discovery of their infection.

In the narratives, people showed a lack of preventive attitudes in the practice of sexual relations due to the consumption of alcoholic beverages. The use of alcoholic beverages contributed for the interviewees to assume the practice of unprotected sex, driven by the feeling of unconcern and the loss of common sense caused by alcohol abuse. In this sense, sexual relations took place freely, motivated by the intense pursuit of pleasure, regardless of the consequences. Studies have pointed out the association between alcohol abuse and inconsistent condom use, the most relevant risk factor for sexual transmission of $\mathrm{HIV}^{(39,42)}$. Research pointed out that approximately half and a third of the sample, respectively, reported having had sex under the influence of alcohol or marijuana, and that men were more likely to engage in sexual relations involving the use of alcohol or drugs ${ }^{(43)}$. The abuse of alcoholic beverages is one of the aspects related to the late presentation of people to care for HIV infection ${ }^{(8)}$.

\section{Study limitations}

As a study limitation, it is considered that participants represent only people who were diagnosed late in health services, not including those who discovered HIV infection in a timely manner. Thus, it is suggested to carry out new studies that cover this audience, in addition to research that considers the perspective of health professionals and managers at all levels of care in the Unified Health System (Sistema Único de Saúde).

\section{Contributions to nursing and health}

The results of this study provided a more in-depth knowledge of this serious public health problem, which is the delayed diagnosis of HIV and, therefore, are expected to contribute to the design of new strategies and policies aimed at timely diagnosis. Moreover, 
the findings may lead health and nursing professionals to reflect on and change their practices, with regard to the dialogical approach to sexuality in care and the (re) construction of new representations about sexuality and HIV/aids that favor early diagnosis.

\section{FINAL CONSIDERATIONS}

The results revealed representations related to sexuality and the experiences of sexual affective relationships, which were central to PLHIV's life trajectories and influenced delayed diagnosis. Although there are gender issues that interfered in the decision to practice unprotected sex, mainly related to hegemonic masculinity conceptions and behaviors, both men and women chose to practice sex without a condom, motivated by the representation of the search for pleasure in the sexual or love relationship romantic, regardless of the risk of infections, which stood out for its strong anchorage in the social imaginary and for its centrality in the experience of sexuality.

The narratives also showed that the process of (in) vulnerability to HIV started in the adolescence period, revealing the representation of sexuality as a taboo, revealed in silencing within the family, or in its superficial and normative approach in the daily life of health services. In the relational dimension, the attitude of trust in the experience of stable relationships is emphasized, which contributed to the non-use of condoms during sexual intercourse, as well as to lack of periodic screening for the virus after these unprotected relationships, corroborating the delayed discovery of HIV infection.

The lack of perception of their own vulnerability to HIV/AIDS, associated with the naturalization of sex without a condom, as a synonym for freedom and intense pleasure, and the attitude of trust in a fixed partnership, contributes to the fact that people discover their serological status at a late stage, extending the period of transmission of the virus in the community.

It is highlighted as the main consequence of lack of perception of individual vulnerability, the failure to carry out primary and secondary prevention actions, such as the use of condoms during sexual intercourse and periodic screening for the virus after exposure situations. These factors contribute together so that susceptible individuals do not discover their seropositivity early, incurring a delayed diagnosis.

\section{REFERENCES}

1. Op de Coul ELM, van Sighem A, Brinkman K, van Benthem BH, van der Ende ME for the ATHENA national observational HIV cohort, et al. Factors associated with presenting late or with advanced HIV disease in the Netherlands, 1996-2014: results from a national observational cohort. BMJ Open. 2016;6:e009688. https://doi.org/10.1136/bmjopen-2015-009688

2. Lifson AR, Grund B, Gardner EM, Kaplan R, Denning E, Engen N, et al. Improved quality of life with immediate versus deferred initiation of antiretroviral therapy in early asymptomatic HIV infection. AIDS. 2017;31(7):953-63. https://doi.org/10.1097/QAD.0000000000001417

3. Valentini MB, Toledo MLG, Fonseca MO, Thiersch LMS, Toledo ISB, Machado FCJ, et al. Evaluation of late presentation for HIV treatment in a reference center in Belo Horizonte, Southeastern Brazil, from 2008 to 2010. Braz J Infect Dis. 2015;19(3):253-62. https://doi.org/10.1016/j.bjid.2015.01.005

4. Ribeiro LCS, Freitas MIF, Tupinambás U, Lana FCF. Late diagnosis of Human Immunodeficiency Virus infection and associated factors. Rev Latino-Am Enfermagem. 2020;28:e3342. https://doi.org/10.1590/1518-8345.4072.3342

5. Mocroft A, Lundgren JD, Antinori A, Monforte Ad, Brännström J, Bonnet F, et al. Late presentation for HIV care across Europe: update from the Collaboration of Observational HIV Epidemiological Research Europe (COHERE) study, 2010 to 2013. Euro Surveill. 2015;20(47):pii=30070. https://doi.org/10.2807/1560-7917.ES.2015.20.47.30070

6. Sobrino-Vegas P, Moreno S, Rubio R, Viciana P, Bernardino Jl, Blanco JR, et al. Impact of late presentation of HIV infection on short-, mid-and long-term mortality and causes of death in a multicenter national cohort: 2004-2013. J Infect. 2016;72(5):587-96. https://doi.org/10.1016/j. jinf.2016.01.017

7. Beyene MB, Beyene HB. Predictors of Late HIV Diagnosis among Adult People Living with HIV/AIDS Who Undertake an Initial CD4 T Cell Evaluation, Northern Ethiopia: a case-control study. PLoS One. 2015;10(10):e0140004. https://doi.org/10.1371/journal.pone.0140004

8. Yadav UN, Chandrasekharan V, Guddattu V, Gruiskens J. Mixed method approach for determining factors associated with late presentation to HIV/AIDS care in southern India. J Postgrad Med. 2016;62(3):173-77. https://doi.org/10.4103/0022-3859.183169

9. Joore IK, Arts DL, Kruijer MJ, van Charante EPM, Geerlings SE, Prins JM, et al. HIV indicator condition-guided testing to reduce the number of undiagnosed patients and prevent late presentation in a high-prevalence area: a case-control study in primary care. Sex Transm Infect. 2015;91:467-72. https://doi.org/10.1136/sextrans-2015-052073

10. Gargallo-Bernad C, Sangrós-González FJ, Arazo-Garcés P, Martínez-Álvarez R, Malo-Aznar C, Gargallo-Bernad A, et al. Oportunidades perdidas en el diagnóstico de la infección por el virus de inmunodeficiencia humana en la Comunidad de Aragón. Importancia del diagnóstico tardio. Enferm Infecc Microbiol Clin. 2018;37(2):100-08. https://doi.org/10.1016/j.eimc.2018.03.007

11. Ribeiro LCS, Giami A, Freitas MIF. Representations of people living with HIV: influences on the late diagnosis of infection. Rev Esc Enferm USP. 2019;53:e03439. https://doi.org/10.1590/S1980-220X2018009703439

12. Lobo ALSF, Santos AAP, Pinto LMTR, Rodrigues STC, Barros LJD, Lima MGT. Representações sociais de mulheres frente à descoberta do diagnóstico do HIV. Rev Pesqui: Cuid Fundam. 2018;10(2):334-42. https://doi.org/10.9789/2175-5361.2018.v10i2.334-342

13. Nemer CRB, Sales BLD, Ranieri BC, Lemos LL, Santos ISR, Pena FPS, et al. HIV e teste rápido: representações sociais. Rev Enferm UFPE. 2019;13:e239280. https://doi.org/10.5205/1981-8963.2019.239280 
14. Sivhabu V, Visser M. Constructions of sexuality and HIV risk among young people in Venda, South Africa: implications for HIV prevention. Afr J AIDS Res. 2019;18(2):158-67. https://doi.org/10.2989/16085906.2019.1630449

15. Mora C, Brigeiro M, Monteiro S. A testagem do HIV entre "HSH": tecnologias de prevenção, moralidade sexual e autovigilância sorológica. Physis. 2018;28(2):e280204. https://doi.org/10.1590/s0103-73312018280204

16. Alencar RA, Ciosak SI. Aids em idosos: motivos que levam ao diagnóstico tardio. Rev Bras Enferm. 2016;69(6):1140-46. https://doi. org/10.1590/0034-7167-2016-0370

17. Ribeiro LCS, Freitas MIF. Representações sobre sexualidade de pessoas vivendo com HIV e o diagnóstico atrasado da infecção [Internet]. In: Silva DGV, Ramos FRS, Girondi JBR, Cunha K, Verdi M, Finkler M, et al., editors. Anais do VIII Congresso Iberoamericano de Pesquisa Qualitativa em Saúde; 2018 Sep 04-06; Florianópolis (SC):Universidade Federal de Santa Catarina/ Programa de Pós-Graduação em Enfermagem; 2018 [cited 2021 Jun 02]. p. 801-03. Available from: https://attitudepromo.iweventos.com.br/upload/cartas/files/Anais\%20 VIII\%20CIICS\%20FINAL\%20WEB(1).pdf

18. Giami A, Veil C. Enfermeiras frente à Aids: representações e condutas, permanência e mudanças. Canoas: Ulbra; 1997. 333 p.

19. Minayo MCS. Amostragem e saturação em pesquisa qualitativa: consensos e controvérsias. Rev Pesqui Qual [Internet]. 2017 [cited 2020 Feb 10];5(7):01-12. Available from: https://www.researchgate.net/publication/315756131

20. Demazière D, Dubar C. Analyser les entretiens biographiques: l'example de récits d'insertion. Paris: Nathan, Coll. Essais \& recherches; 1997.350 p.

21. Gagnon JH. Uma interpretação do desejo: ensaios sobre o estudo da sexualidade. Rio de Janeiro: Garamond; 2006.456 p.

22. Oltramari LC, Camargo BV. AIDS, relações conjugais e confiança: um estudo sobre representações sociais. Psicol Estud. 2010;15(2):275-83. https://doi.org/10.1590/S1413-73722010000200006

23. Sousa LMS, Silva LS, Palmeira AT. Representações sociais de caminhoneiros de rota curta sobre HIV/AIDS. Psicol Soc. 2014;26(2):346-55. https://doi.org/10.1590/S0102-71822014000200011

24. Garcia S, Berquó E, Lopes F, Lima LP, Souza FM. Práticas sexuais e vulnerabilidades ao HIV/aids no contexto brasileiro: considerações sobre as desigualdades de gênero, raça e geração no enfrentamento da epidemia. Demografia Debate [Internet]. 2015 [cited 2020 Feb 10];2:417-47. Available from: http://www.abep.org.br/ abeporgb/publicacoes/index.php/ebook/article/viewFile/59/57

25. Bezerra EO, Pereira MLD, Chaves ACP, Monteiro PV. Representações sociais de adolescentes acerca da relação sexual e do uso do preservativo. Rev Gaúcha Enferm. 2015;36(1):84-91. https://doi.org/10.1590/1983-1447.2015.01.45639

26. Frois E, Moreira J, Stengel M. Mídias e a imagem corporal na adolescência: o corpo em discussão. Psicol Estud. 2011;16(1):71-7. https://doi. org/10.1590/S1413-73722011000100009

27. Sousa MA. Representações de adolescentes sobre HIV/aids com enfoque na sexualidade e na vulnerabilidade às infecções sexualmente transmissíveis [Dissertação]. Belo Horizonte: Universidade Federal de Minas Gerais, Escola de Enfermagem; 2017. 140 p.

28. Nubed CK, Akoachere JTK. Knowledge, attitudes and practices regarding HIV/AIDS among senior secondary school students in Fako Division, South West Region, Cameroon. BMC Public Health. 2016;16(1):847. https://doi.org/10.1186/s12889-016-3516-9

29. Lee Y-H, Salman A, Cooksey-James T. Gender Differences in HIV/AIDS Preventive Self-Efficacy Among Taiwanese Adolescents. AIDS Educ Prev. 2016;28(1):77-89. https://doi.org/10.1521/aeap.2016.28.1.77

30. Mesquita JS, Costa MIF, Luna IT, Silva AA, Pinheiro PNC. Fatores de risco e de proteção entre adolescentes em relação às DST/HIV/AIDS. Rev Enferm UFPE. 2017;11(3):1227-33. https://doi.org/10.5205/reuol.10544-93905-1-RV.1103201713

31. Woldeyohannes D, Asmamaw Y, Sisay S, Hailesselassie W, Birmeta K, Tekeste Z. Risky HIV sexual behavior and utilization of voluntary counseling and HIV testing and associated factors among undergraduate students in Addis Ababa, Ethiopia. BMC Public Health. 2017;17(121). https://doi. org/10.1186/s12889-017-4060-y

32. Petitat A. Secret et formes sociales. Paris: PUF; 1998. p. 81-113.

33. Giddens A. A transformação da intimidade: sexualidade, amor e erotismo nas sociedades modernas. 2 ed. São Paulo: UNESP; 1993. 228p.

34. Yang Y, Wojnar D, Lewis FM. Becoming a person with HIV: experiences of Cambodian women infected by their spouses. Cult Health Sex. 2016;18(2):198-210. https://doi.org/10.1080/13691058.2015.1064164

35. Panarra BACS, Teixeira E, Palmeira IP, Rodrigues ILA, Ferreira AMR. Vítimas e culpadas: representações sociais sobre mulheres que vivem com HIV. Rev Cuid. 2017;8(3):1887-98. https://doi.org/10.15649/cuidarte.v8i3.451

36. Arraes CO, Palos MAP, Barbosa MA, Teles SA, Souza MM, Matos MA. Masculinidade, vulnerabilidade e prevenção relacionadas às doenças sexualmente transmissíveis/HIV/Aids entre adolescentes do sexo masculino: representações sociais em assentamento da reforma agrária. Rev Latino-Am Enfermagem. 2013;21(6):1266-73. https://doi.org/10.1590/0104-1169.3059.2363

37. Giami A. Permanência das representações do gênero em sexologia: as inovações científica e médica comprometidas pelos estereótipos de gênero. Physis. 2007;17(2):301-20. https://doi.org/10.1590/S0103-73312007000200006

38. Pinheiro PNC, Ferreira AGN, Dias FLA, Silva KL, Scopacasa LF, Gubert FA. Relação entre infidelidade e infecção ao HIV/aids na visão de homens heterossexuais. Cienc Enferm. [Internet]. 2012 [cited 2018 Aug 10];XVIII(3):39-48. Available from: https://www.redalyc.org/articulo.oa?id=370441811005

39. Baptista CJ, Dourado I, Andrade TM, Brignol S, Bertoni N, Bastos Fl, et al. HIV prevalence, knowledge, attitudes, and practices among polydrug users in Brazil: a biological survey using respondent driven sampling. AIDS Behav. 2018;22:2089-103. https://doi.org/10.1007/ s10461-017-1812-8 
40. Costa C, Lima ML. O papel do amor na percepção de invulnerabilidade à sida. Psicologia. 1998;12(1):41-62. https://doi.org/10.17575/rpsicol. v12i1.572

41. Taylor SE, Brown JD. Illusion and well-being: a social psychological perspective on mental health. Psychol Bull [Internet]. 1988 [cited 2018 Aug 10];103(2):193-210. Available from: http://citeseerx.ist.psu.edu/viewdoc/download?doi=10.1.1.385.9509\&rep=rep1\&type=pdf

42. Sperhacke RD, Motta LR, Kato SK, Vanni AC, Paganella MP, Oliveira MCP, et al. HIV prevalence and sexual behavior among young male conscripts in the Brazilian army, 2016. Medicine (Baltimore). 2018;97(1S):S25-S31. https://doi.org/10.1097/MD.0000000000009014

43. Marshall BDL, Perez-Brumer AG, MacCarthy S, Mena L, Chan PA, Towey C, et al. Individual and partner-level factors associated with condom non-use among African American STI Clinic Attendees in the Deep South: an event-level analysis. AIDS Behav. 2016;20(6):1334-42. https:// doi.org/10.1007/s10461-015-1266-9 